\title{
THE EFFECT OF EDUCATIONAL COMPUTER GAMES ON THE VOCABULARY LEARNING PERFORMANCE OF TURKISH MIDDLE SCHOOL EFL STUDENTS
}

\author{
Mahmut Zengin, \\ Nuray Yilmazi \\ Bursa Uludag University, \\ Bursa, Turkey
}

\begin{abstract}
:
This study aims to establish the effects of educational computer games on the vocabulary learning of EFL students. In the research, the real experimental model with a pretest/post-test control group was used. The application of the study was carried out with 5th grade EFL students in two middle schools. The study group consisted of 166 students in the experimental group and 171 students in the control group. Five different games have been developed for use in research, including selection-matching-space-filling games, memory games, word capture games, crossword games, and millionaire games. Games were prepared by using Adobe Captivate 9.0 program. The students in the experimental group learned through educational computer games. The students in the control group learned according to the current program. Data were collected by applying the academic achievement test before and after one month of the experiment. To analyze the data were used quantitative data methods; T-Test for independent samples, $t$-Test for dependent samples, Mann-Whitney U test, and Wilcoxon signed-rank test. The results of the study indicate that the students who learned vocabulary with educational computer games were more successful than the students who learned according to the current program. The learning in the experimental group is more retention than in the control group.
\end{abstract}

Keywords: educational computer games; L2; FL; 5th grade; middle school; vocabulary learning; vocabulary retention

\section{Introduction}

Vocabulary plays an important role in second language (L2) / foreign language (FL) learning (Schmitt, 2008). Previous research findings revealed that vocabulary has an effect on the acquisition of other skills composing language acquisition (for example,

${ }^{i}$ Correspondence: email npyilmaz@uludag.edu.tr 
reading comprehension (Lervåg \& Aukrust, 2010; Li \& Kirby, 2015; Masrai, 2019; Qian, 2002; Stæhr, 2008) and listening skills (Cheng \& Matthews, 2018; Matthews \& Cheng, 2015; Matthews, 2018; Stæhr, 2008). However, due to both the nature of the vocabulary learning process and adopted approaches, vocabulary learning could be both intimidating and boring for many students (Tsai \& Tsai, 2018; Yip \& Kwan, 2006). Of course, this may lead students to lose their interest in learning vocabulary (Yip \& Kwan, 2006). For this reason, language learners need effective vocabulary learning approaches (Zou \& Xie, 2019). On the one hand, new tools are being developed for this purpose (Tsai \& Tsai, 2018). One of these tools is digital games. Researchers have been in search of new learning strategies aiming to make digital game- assisted language learning more effective (Zhang, 2018).

Due to their potential effects on L2 /FL learning, digital games have provided the inspiration for numerous studies in the last 30 years. Depending on this, the digital gamebased learning area has been growing rapidly (Cornillie, Clarebout, \& Desmet, 2012; Hwang \& Wu, 2012; Poole \& Clarke-Midura, 2020). An important part of the studies carried out in this learning area focused on the investigation of the effect of digital games on vocabulary knowledge/ acquisition (Hung et al., 2018; Tsai \& Tsai, 2018; Zhang, 2018). In the studies carried out in this area, mostly teaching of English was chosen as the target language probably due to the prevalence of its use (Acquah \& Katz, 2020; Chiu, Kao, \& Reynolds, 2012). Most of the previous studies indicated that the Digital Game- Based Language Learning (DGBLL) approach was effective in language acquisition (Hung et al., 2018). While some empirical studies reported that digital games had a positive effect on L2 vocabulary acquisitions, others put forward negative or mixed results. However, some studies have shown opposite or mixed findings (Sundqvist \& Wikström, 2015). The metaanalysis study carried out by Tsai and Tsai (2018) revealed that DGBLL was more effective in L2 vocabulary success with a great effect dimension compared to traditional teaching. Again, according to the literature review carried out by Zou, Huang and Xie (2019), the research results indicated that digital games generally had positive effects on the encouragement of short-term and long-term vocabulary learning. Starting from the studies made with 6-18-aged participants in their literature review, Acquah and Katz (2020) revealed the positive effect of digital games on language learning.

Although DGBLL is a gradually growing research area, there is still a lack of empirical evidence (Godwin-Jones, 2014) and insufficient literature (Hung et al., 2018) in relation to the effectiveness of digital games in language education. On the other hand, starting from the necessity of starting language education at early ages, it can be stated that there is a need for focusing on digital games aiming to have children and adolescents learn L2. Hence, research findings can be applied more reliably to teaching and curriculum in primary and secondary schools (Acquah \& Katz, 2020). For this reason, researchers should provide research results that are suitable for different ages and teaching programs via studies which they will carry out.

On the other hand, despite the importance attached to the learning of English in our country, the targeted success in English teaching has not been reached yet (Anşin, 2006; Gömleksiz \& Aslan, 2017; Oflaz, 2017). It is considered that a variety of factors have 
an effect on the failure in English teaching. Of these, the most outstanding ones are the problems related to teachers' competencies, students' willingness and attitudes, course materials, teaching methods, and learning environment (Aktaş, 2005). Moreover, when the subject is taken in hand according to the teaching stages, it is observed that since secondary school students cannot learn Turkish meanings of English words accurately, their success levels in lessons are low. This affects students' attitudes toward lessons and will to succeed negatively (Anşin, 2006; Oflaz, 2017).

When problems experienced in relation to foreign language teaching/ learning in Turkey and the needs of new generation learners, on the other hand, are taken into consideration, it is observed that the need for new teaching approaches embodying technology, too, is increasing. Starting from the results of previous studies, it can be stated that the use of digital games with the purpose of learning a language is more promising compared to other learning domains (Young et al., 2012). Hence, the production of this kind of game in Turkey and investigation into the effects of already produced, existing games on language learning outputs are important in terms of the contribution they are likely to make to the field. Research in the literature is increasing year by year. The industrial developments, new academic formations, various non-governmental organizations (NGOs) and novelties in public policies observed in relation to digital games in Turkey especially following the second millennium have affected the literature on digital games as well (Sezgin, Binark, Yalçın, \& Bayraktutan, 2018). However, when the investigation in the research area is narrowed down to the field of education and by taking into account the effect of digital games on different learning domains, particularly foreign language/ L2 teaching/learning as a single learning domain, and the variable of age in this field, the number gradually decreases.

This study aims to establish the effects of educational computer games on the vocabulary learning of EFL students. The questions to be investigated in the direction of the present study and the sub-research questions related to these questions are as follows:

1. Is there a difference between the success levels of the students learning English vocabulary in the learning environments in which educational computer games are used and not used?

1.1 Is there a significant difference between the academic success pre-test scores of the experimental and the control group students?

1.2 Is there a significant difference between the academic success post-test scores of the experimental and the control group students?

2. Is there a significant difference between the learning environments in which educational computer games are used and not used in terms of the retention of what is learned?

2.1 Is there a significant difference between the experimental group students' academic success post-test scores and the follow-up test scores?

2.2 Is there a significant difference between the control group students' academic success post-test scores and the follow-up test scores? 
2.3 Is there a significant difference between the experimental and the control group students' follow-up test scores?

\section{Literature Review}

\subsection{Learning Outcomes related to English Vocabulary Acquisition with Educational Computer Games}

\subsubsection{Vocabulary Learning}

In the literature, there are some empirical studies made on foreign language/ vocabulary learning with digital games and literature reviews, and meta-analysis studies aiming to evaluate the results of these studies. The results of the meta-analysis study made by Tsai and Tsai (2018) suggest that the learning with digital games can effectively motivate and enhance students' L2 vocabulary learning. Moreover, research findings indicate that different factors in games including various learning scenarios might lead to extremely different learning outcomes as well. When elementary school students are a matter of discussion, DGVL yields the best result in task-based games. According to the results of the meta-analysis made by Chiu, Kao, and Reynolds (2012) with 14 empirical studies published between the years of 2005-2010, the digital games in EFL created an effect a moderate level. When it was taken in hand from the point of types of games, it was determined that the drill and praxis games created a little effect dimension. Moreover, in their study, Yip and Kwan (2006) used online drill praxis type of vocabulary games, too. The qualitative and quantitative results, which the researchers obtained from their study, which lasted nine weeks with undergraduate students, indicated that the students learning English vocabulary with this kind of game showed better performance levels and learned more words compared to the ones in the experimental group. The study shows that vocabulary learning can be developed greatly with the drill and the praxis types of games.

In some of the recently-made literature reviews, some results indicated that digital games supported vocabulary learning (Hung et al., 2018; Zou \& Xie, 2019). This first of these studies was carried out by Hung et al. (2018). The studies taken in hand in the researchers' content analysis study were mostly empirical and carried out with university students. In most of the studies, the games were used with the aim of learning English as L2 and EFL. In the studies, the most frequently examined learning output category was emotional or psychological states as closely followed by language acquisition. In language acquisition, most of the evidence was related to the development of vocabulary. According to this study, in order to facilitate the learners' vocabulary acquisition, exercise games were commonly adopted.

The second study was the literature review made by Zou, Huang, and Xie (2019). The results indicated that teaching and learning vocabulary with digital games was more effective compared to the traditional approaches. The investigated studies revealed that digital games mostly support students to keep words in their memory (short and long term), understand what they read and listen to, and improve their pronunciation. 
Moreover, the researchers stated that the types of digital games used in the studies under examination were very simple and limited features.

Previous studies carried out with elementary school students indicated that DGVL encouraged effective vocabulary teaching and learning (Aghlara \& Tamjid, 2011; Alsharafat, Alrashdan, \& Younes, 2017; Ashraf, Motlagh, \& Salami, 2014; Ceylaner \& Yanpar Yelken, 2017; Ebrahimzadeh, 2017; Jensen, 2017; Hung, Young, \& Lin, 2015; Kocaman \& Kizılkaya Cumaoğlu, 2014; Letchumanan, Tan, Paramasivam, Sabariah, \& Muthusamy, 2015; Liu \& Chu, 2010; Hong et al., 2016). In the study made by Hung et al. (2015) with elementary school 6th -grade students, DGVL became effective on the students showing low levels of success. The researchers investigated the effects of cooperation and competition strategies. According to Gee (2007), the reason why computer games are useful especially for students with low levels of success is that games provide a secure medium for practice (Cited by Hung et al., 2018).

Kocaman and Kizılkaya Cumaoğlu (2014) reached the result that different types of educational software used in vocabulary teaching had positive effects on vocabulary learning. In a study carried out by Ceylaner and Yanpar Yelken (2017) with secondary school students, the students gave positive opinions about the fact that digital games contributed to vocabulary learning and communication. However, some studies did not support the above-mentioned result. However, some studies did not support the abovementioned result (Jalali \& Dousti, 2012; Lucht \& Heidig, 2013).

\subsubsection{Vocabulary Retention}

Some previous studies (Donmuş, 2012; Yip \& Kwan, 2006; Young \& Wang, 2014; Huang \& Huang, 2015) examined the effect of DGVL on permanent learning. Donmuş (2012) found in his research with 6th- grade students that educational computer games make a significant contribution to the retention of learning English. In the same way, the nineweek lasting study carried out by Yip and Kwan (2006) with undergraduate students indicated that the students could retain the learned English vocabulary for a longer period of time via games. The meta-analysis study carried out by Zhang (2018) indicated that educational games did not have an effect on long-term vocabulary retention. Young and Wang (2014) carried out their study with 4th-grade students. A week after the experiment, in the word retrieval test, the students using the drill and praxis method showed better performance than the ones in the experimental group doing a game-based exercise. Huang and Huang (2015) carried out their study with university students. The results indicated that the students included in the experimental group under three categories (low-medium and high achieving) did not have higher retention levels than the ones included in the control group. The researchers asserted that since the game which they had developed did not provide the chance of exercising and practicing, it did not help the students retrieve the words which they had learned. They suggested if students were given a chance of exercising and practicing, they could keep information in their long-term memory for a long period of time. 
Numerous studies were made with participants of different ages on the effect of intermittent repetitions on keeping vocabulary within the course of time in L2 courses. The results showed that information could even be retained for a few years (Varela, 2020). Varela (2020) conducted a study in which high school students learn Spanish words by repeating them. Students learned 100 words in 11 sessions and repeated the words every 30 days. The students' vocabulary was checked after one month, two months, and 70 days. The research revealed the importance of spaced repetition in permanent vocabulary learning.

\section{Material and Methods}

In this study, the true experimental model with pretest and post-test control groups was applied. The common characteristics of true experimental models are the use of more than one group and the creation of groups with unbiased sampling (Büyüköztürk, Çakmak, Akgün, Karadeniz, \& Demirel, 2016).

\subsection{Participants}

The study was carried out with a total of 337 th grade students enrolled in two public schools within the 2018-2019 second semesters. The students' classes were accepted as their groups. The primary school success levels of the students were similar.

Table 3.1: Distribution of the students according to the schools and the groups

\begin{tabular}{|l|c|c|c|c|c|c|}
\hline \multirow{2}{*}{ Schools } & \multicolumn{3}{|c|}{ Experimental Group } & \multicolumn{3}{c|}{ Control Group } \\
\cline { 2 - 7 } & Class & Number & Percentage & Class & Number & Percentage \\
\hline \multirow{3}{*}{ A Secondary School } & 1B & 37 & 11,0 & $1 \mathrm{D}$ & 38 & 11,3 \\
& 1F & 33 & 9,8 & $1 \mathrm{E}$ & 37 & 11,0 \\
& 1H & 33 & 9,8 & $1 \mathrm{G}$ & 34 & 10,1 \\
\hline \multirow{3}{*}{ B Secondary School } & 1A & 23 & 6,8 & $1 \mathrm{~B}$ & 24 & 7,1 \\
& 1C & 24 & 7,1 & $1 \mathrm{D}$ & 18 & 5,3 \\
\hline Total & 1E & 16 & 4,7 & $1 \mathrm{~F}$ & 20 & 5,9 \\
\hline
\end{tabular}

The groups were determined randomly. The number of the students in the experimental group was 166 and that of the students in the control group was 171. In Table 3.1 the distribution of the students according to the schools and the groups is seen.

\subsection{Instruments}

The games used in the study were prepared by using Adobe Captivate 9 program. The prepared games are these: the choosing- matching- fill in the blanks games, the memory games, the catchword games, the crossword games, and the millionaire games. These games are tutorial types of games (drill and praxis). According to Prensky (2001), rules, goals and objectives, feedbacks, struggle, race, challenge and opposition, interaction, 
presentation, and story are the fundamental characteristics that need to exist in educational games. Games were prepared by taking into account these characteristics.

The educational computer games developed to be used in the study were prepared by considering the "My Town" unit included in the MNE 2018-2019 educational year 1st - semester curriculum of the 5th grade English. The words taught via games in the unit were given in Table 3.2 below. As can be seen in Table 3.2, the 1st group included the words related to common fields and education, the 2nd group was composed of the words related to shopping and the 3rd group consisted of the words related to directions. Prior to the preparation of the games, the teaching order of the words was determined.

Table 3.2: The word list to be taught

\begin{tabular}{|c|c|c|c|}
\hline Rank & $\begin{array}{c}\text { 1st Group } \\
\text { of words }\end{array}$ & $\begin{array}{c}\text { 2nd Group } \\
\text { of words }\end{array}$ & $\begin{array}{c}\text { 3rd Group } \\
\text { of words }\end{array}$ \\
\hline 1 & Bakery & Bus stop & Behind \\
\hline 2 & Bank & Castle & Between \\
\hline 3 & Barber & Palace & Opposite \\
\hline 4 & Cafe & Train station & Next to \\
\hline 5 & Teacher & Stationery & Around \\
\hline 6 & School & Toy shop & Turn left \\
\hline 7 & Library & Book shop & Take the first left \\
\hline 8 & Post Office & Pool & Turn right \\
\hline 9 & Pharmacy & Supermarket & Take the second right \\
\hline 10 & Hospital & & It is on right \\
\hline 11 & Mosque & & \\
\hline 12 & Cinema & & \\
\hline
\end{tabular}

In the process of preparing the games, a software specialist was asked for his opinion about visually and design. In the direction of the specialist's suggestions, additions and corrections were made in the games. The English teachers were asked to evaluate the prepared games in terms of their suitability for the unit coverage, goals and objectives. In the direction of the teachers' suggestions, some corrections were made in the games. Moreover, two specialists servicing in the department of Computer and Teaching Technologies were asked for their opinions about the games by using the forms prepared by the researcher. In the direction of the specialists' opinions, corrections were made and the games were finally revised.

The pilot study of the games prepared in accordance with the opinions taken from the specialists and the teachers was carried out with 10 secondary 2nd grade students. The students were observed during the implementation and the problems which they experienced and their questions were noted down. Hence, possible problems to arise during the implementation were eliminated. The final versions of the games were looked over together with the English teachers and then they were practiced. 


\begin{tabular}{|l|l|}
\hline \multicolumn{2}{|c|}{ Table 3.3: The experimental design } \\
\hline Implementation (4 Weeks) & Control Groups \\
\hline Experimental Groups & Taking the pre-test \\
\hline Taking the pre-test & Word learning without games \\
\hline Word learning with games & {$[$ Total 6 lesson hours $(2+1+2+1)]$} \\
{$[$ Total 6 lesson hours $(2+1+2+1)]$} & Teaching in Classroom \\
\hline Teaching in Classroom & (Total 6 lesson hours) \\
(Total 6 lesson hours) & Activities and homework \\
Activities and homework & Taking the post-test \\
\hline Taking the post-test & Taking the follow-up test (after one month) \\
\hline Taking the follow-up test (after one month) &
\end{tabular}

Implementation process of the study are summarized in Table 3.3.The five prepared educational computer games were played by the students included in the experimental group within a total of 6 lesson hours, namely two hours in the first week, one lesson hour in the second week, two lesson hours in the third week, and one lesson hour in the fourth week. The games played every week were played with one-week intervals. While the games were played, the teacher was in the position of an observer to make sure that the games were played regularly and correctly. In the other half of the implementation (six- lesson hours), as it was in the control group, the activities planned together with the branch teachers within the scope of the unit were implemented in the classroom. In the meantime, in order to eliminate the differences between teachers, the list of activities to be implemented and the implementation program were given to all the teachers. For the implementation, six teachers took charge in the classrooms. With the aim of eliminating the differences between the teachers included in the experimental and the control groups, each of the teachers was made to perform the implementation both in the experimental and the control group. However, in the control group, the teaching did not interfere. The lessons went on in the direction of the sequence of teaching given in the coursebook. The lessons were taught by the branch teachers. Moreover, as it was in the experimental group, the students included in the control group were allotted six- lesson hours for vocabulary teaching. In order to eliminate the difference between the teachers included in the control group and make the activities the same for the students included in the control group, the teachers were given the program to be followed and the documents to be used (unit glossary and matching cards) were distributed and the teachers were asked to perform the implementation within this framework.

\subsection{Data analysis}

The data collected in the study were analyzed via SPSS 24 program. In the analysis of the study data, Independent Samples T-Test and Dependent Samples T-Test were used.

Moreover, in order to learn the homogeneity of the variances of the groups, Levene's test was made. If the p-value obtained as a result of the Levene's test is bigger than .05 ( $p>.05$ ), the variances of the groups are accepted as equal (Büyüköztürk, Çokluk, \& Köklü, 2016; Can, 2018). 
Following the analysis, if there is a significant difference between the compared means can be calculated. However, the obtained value does not give any information about the size of this difference. For this reason, besides the statistical significance, the size of the effect requires calculating as well (Can, 2018). According to Green and Salkind (2005), the effect size in the Independent Samples T-Test and Dependent Samples T-Test can be calculated by using the $t$ value (Cited by Can, 2018). The effect size for this hypothesis was calculated by using the following formula.

The effect size for the Independent Samples T-Test was calculated via the following formula.

$$
d=t \times \sqrt{\frac{N_{1}+N_{2}}{N_{1} \times N_{2}}},
$$

The effect size for the Dependent Samples T-Test was calculated via the following formula.

$$
\mathrm{d}=\frac{\mathrm{t}}{\sqrt{\mathrm{N}}}
$$

According to Green and Salkind (2005), the effect size is evaluated independently from the $d$ sign. It may take every value. An effect size value (d) of 0 (zero) indicates equal means, an effect size of .2 indicates a low effect, an effect size of .5 indicates a moderate effect and an effect size of .8 indicates a big effect (Cited by Can, 2018).

\section{Results}

\subsection{Results related to the achievement test}

Is there a difference between the achievement levels of the students learning English vocabulary in the learning environments in which the educational computer games are used and not used? The findings related to the sub-questions to which answers were sought within the scope of this research question were given below.

\subsubsection{Is there a significant difference between the academic achievement pre-test scores of the students included in the experimental and the control groups?}

The Independent Samples t-Test was conducted to test this sub-research question. Table 4.1 below shows the normality test results related to the academic achievement pre-test scores of the groups. In the normality tests of the groups, the Kolmogorov-Smirnov $p$ values were found to be $p=.082$. Since the obtained $p$-value is higher than $p=.05$, the data obtained from the groups showed normal distribution.

Table 4.1: Normality test results of the pre-test scores of the groups

\begin{tabular}{|l|c|c|c|}
\hline Kolmogorov-Smirnov & Statistics & $\mathbf{N}$ & $\mathbf{p}$ \\
\hline Groups & .065 & 166 & .082 \\
\hline Experimental & .064 & 171 & .082 \\
\hline Control & & & \\
\hline
\end{tabular}

To determine the equality of the variances of the groups, Levene's test was applied. As a result of Levene's test, the p-value was found to be higher than .05 ( $p=.955)$ ( Table 2.2). According to this, the variances of the groups are equal. 
Table 2.2: Independent Samples t-Test results related to the pre-test score means of the groups

\begin{tabular}{|l|c|c|c|c|c|c|c|c|}
\hline \multirow{2}{*}{ Group } & \multirow{2}{*}{$\mathbf{N}$} & \multirow{2}{*}{ Mean } & \multirow{2}{*}{ SD } & \multirow{2}{*}{ Mean Difference } & \multicolumn{2}{|c|}{ Levene's Test } & \multirow{2}{*}{$\mathbf{t}$} & \multirow{2}{*}{ Sig. } \\
\cline { 1 - 3 } & & & & & $\mathbf{F}$ & $\mathbf{p}$ & & \multirow{2}{*}{.275} \\
\hline Coxperimental & 166 & 42.50 & \multirow{2}{*}{335} & 1.92 & .003 & .955 & \multirow{2}{*}{1.093} & .275 \\
\hline
\end{tabular}

Table 4.1 shows the Independent Samples t-Test data. As can be seen in Table 4.1, the mean scores of the pre-test of the control group $(\mathrm{M}=40.58)$ and the experimental group $(\mathrm{M}=42.50)$ is close. When being compared, it can be seen that there is no difference in the mean scores between both groups $(t=1.093$, sig. $=0.275>0.05)$. In other words, there is no difference between the academic achievement levels of both groups before the treatment.

\subsubsection{Is there a significant difference between the academic achievement post-test scores of the students included in the experimental and the control groups?}

The Independent Samples t-Test was conducted to test this sub-research question. In the normality tests of the groups, the Kolmogorov- Smirnov p-value of the experimental group is to be $p=.058$ and the control group as $p=.090$. Since the obtained $p$-value is higher than $\mathrm{p}=.05$, the data obtained from the groups show normal distribution. Table 4.3 below shows the normality test results related to the academic achievement post-test scores of the groups.

Table 4.3: Normality test results of the post-test scores of the groups

\begin{tabular}{|l|c|c|c|}
\hline Kolmogorov-Smirnov & Statistics & $\mathbf{N}$ & $\mathbf{p}$ \\
\hline Group & .068 & 166 & .058 \\
\hline Experimental & .063 & 171 & .090 \\
\hline Control & & & \\
\hline
\end{tabular}

Moreover, to determine the equality of the variances of the groups, Levene's test was applied. As a result of Levene's test, the obtained $p$-value was found to be higher than .05 $(\mathrm{p}=.634>\mathrm{p}=.05)$ (Table 4.4). According to this, the variances of the groups are equal.

Table 4.4: Independent Samples t-Test results

belonging to the post-test score means of the groups

\begin{tabular}{|c|c|c|c|c|c|c|c|c|}
\hline \multirow{2}{*}{ Group } & \multirow{2}{*}{$\mathbf{N}$} & \multirow{2}{*}{ Mean } & \multirow{2}{*}{ SD } & \multirow{2}{*}{$\begin{array}{c}\text { Mean } \\
\text { Difference }\end{array}$} & \multicolumn{2}{|c|}{ Levene's Test } & \multirow[b]{2}{*}{$\mathbf{t}$} & \multirow{2}{*}{ Sig. } \\
\hline & & & & & $F$ & $p$ & & \\
\hline Experimental & 166 & 68.52 & \multirow{2}{*}{335} & \multirow{2}{*}{4.37} & \multirow{2}{*}{.227} & \multirow{2}{*}{.634} & \multirow{2}{*}{2.237} & \multirow{2}{*}{.026} \\
\hline Control & 171 & 64.15 & & & & & & \\
\hline
\end{tabular}

Table 4.4 shows the Independent Samples t-Test data. As can be seen in the table, after the treatment, the mean score of the experimental group $(\mathrm{M}=68.52)$ is found higher than the mean score of the control group $(\mathrm{M}=64.15)$. When being compared, it can be seen that there is a significant difference between the post-test score means of the experimental and the control groups according to the group variable $[t=2.237$, sig. $=0.026<0.05]$. 
According to this, it can be said that the students who learned vocabulary through educational computer games in the experimental group were more successful than the students in the control group.

The effect size value of the result obtained as a result of the Independent Samples $\mathrm{t}$-Test is $\mathrm{d}=.24$. This value indicates that the size of the difference between the mean scores of the groups participating in the study is little.

\subsubsection{Is there a significant difference between the achievement pre-test and the post- test scores of the students included in the experimental and the control groups?}

The Dependent Samples t-Test was used to test this sub-research question. In Table 4.5 below were given the normality test results belonging to the difference between the academic achievement post-test scores and the pre-test scores of the students experimental and control groups. According to the normality test of the difference between the post-test and pre-test scores of the groups, the Kolmogorov-Smirnov p-value of the experimental group is $p=.056$, and the control group is $p=.073$. Since the obtained $\mathrm{p}$-value is higher than $\mathrm{p}=.05$, the data obtained from the groups show normal distribution.

Table 4.5: Normality test of the difference between the post-test and the pre-test scores of the groups

\begin{tabular}{|l|c|c|c|}
\hline Kolmogorov-Smirnov & Statistics & $\mathbf{N}$ & $\mathbf{p}$ \\
\hline Group & .068 & 166 & .056 \\
\hline Experimental group difference & .065 & 171 & .073 \\
\hline Control group difference & &
\end{tabular}

In Table 4.6 are summarized the results of the Dependent Samples t-Test. Data in Table 4.6 indicate that there is improvement in the students' performance in the experimental group before and after the treatment. As seen in the table, the student's academic posttest mean scores $(M=68.52, S D=165)$ are higher than their pre-test mean scores $(M=42.50$, $\mathrm{SD}=165)$. The mean difference $(\mathrm{MD}=26.02)$ was statistical different $(\mathrm{t}=21.461$, sig. $=.00<$ 0.05). Based on this, it can be said that teaching English vocabulary with educational computer games in the experimental group increased the success levels of the students. The effect size value of the result obtained as a result of the Dependent Samples T-test is $\mathrm{d}=1.67$. This value indicates that English vocabulary teaching performed with educational computer games has a great effect on students' achievement levels.

Table 4.6: Dependent Samples t-Test results related to the academic achievement post-test and pre-test scores of the experimental group

\begin{tabular}{|l|c|c|c|c|c|c|}
\hline Experimental group & $\mathbf{N}$ & Mean & SD & Mean Difference & $\mathbf{t}$ & Sig. \\
\cline { 1 - 3 } Post-test & 166 & 68.52 & \multirow{2}{*}{165} & 26.02 & 21.461 & $\mathbf{. 0 0 0}$ \\
\hline Pretest & 166 & 42.50 & & & & \\
\hline
\end{tabular}

In Table 4.7 are summarized the results of the Dependent Samples t-Test. Data in Table 4.7 indicate that there is improvement in the students' performance in the control group 
before and after the treatment. As seen in the table, the student's academic post-test mean scores $(M=64.15, S D=170)$ are higher than their pre-test mean scores $(M=40.58, S D=170)$. The mean difference $(\mathrm{MD}=13.57)$ was statistical different $(t=19.261$, sig. $=.00<0.05)$. Based on this, it can be said that the success levels of students who learn English vocabulary without educational computer games in the control group also increase.

Table 4.7: Independent Samples t-Test results related to the academic achievement post-test and pre-test scores of the control group

\begin{tabular}{|l|c|c|c|c|c|c|}
\hline Control group & N & Mean & SD & Mean Difference & t & Sig. \\
\cline { 1 - 3 } Post-test & 171 & 64.15 & \multirow{2}{*}{170} & 13.57 & \multirow{2}{*}{19.216} & \multirow{2}{*}{.000} \\
\hline Pre-test & 171 & 40.58 & & & \\
\hline
\end{tabular}

The effect size value of the result obtained as a result of the Dependent Samples t-Test is $\mathrm{d}=1.47$. This value indicates that the English vocabulary teaching performed according to the existing program has a great effect on the students' success levels.

\subsection{Results related to vocabulary retention}

With the follow-up test administered to the students included in the experimental and the control groups one month after the treatment, it was aimed to determine the retention of the learning. Is there a difference between the learning environments in which the educational computer games are used and not used in terms of the retention of what is learned? The findings related to the hypothesis tested about to with concerning research question were given below.

\subsubsection{Is there a significant difference between the follow-up test scores of the students included in the experimental and control groups?}

The Independent Samples t-Test was used to test this sub-research question. The data relating to this test is in Table 4.8 and Table 4.9 below. In the normality tests of the groups, the Kolmogorov-Smirnov p-value of the experimental group was found to be $\mathrm{p}=.094$ and the Kolmogorov-Smirnov $p$-value of the control group was determined as $p=.080$. Since the obtained $p$-value is higher than $p=.05$, the data obtained from the groups show normal distribution. The normality test results of the follow-up test scores of the experimental and control groups were given in Table 4.8 below.

Table 4.8: Normality test of the follow-up test scores of the experimental and control groups

\begin{tabular}{|l|c|c|c|}
\hline Kolmogorov-Smirnov & Statistics & $\mathbf{N}$ & $\mathbf{p}$ \\
\hline Group & .064 & 166 & .094 \\
\hline Experimental & .064 & 171 & .080 \\
\hline Control & & & \\
\hline
\end{tabular}

Moreover, to determine the equality of the variances of the groups, Levene's test was applied. As a result of Levene's test, the obtained p-value was found to be higher than 05 $(p=.580)$ (Table 4.9). According to this, the variances of the groups are equal. 
Table 3 Independent Samples t-Test results related

to the means of the follow-up tests of the groups

\begin{tabular}{|l|c|c|c|c|c|c|c|c|}
\hline \multirow{2}{*}{ Group } & \multirow{2}{*}{$\mathbf{N}$} & \multirow{2}{*}{ Mean } & \multirow{2}{*}{ SD } & \multirow{2}{*}{ Mean Difference } & \multicolumn{2}{|c|}{ Levene's Test } & \multirow{2}{*}{$\mathbf{t}$} & \multirow{2}{*}{$\mathbf{p}$} \\
\cline { 1 - 4 } & & & & & $\mathbf{F}$ & $\mathbf{p}$ & & \\
\hline Experimental & 166 & 65.36 & \multirow{2}{*}{335} & 6.24 & .306 & .580 & \multirow{2}{*}{3.22} & \multirow{2}{*}{$\mathbf{0 1}$} \\
\hline
\end{tabular}

Table 4.9 shows the Independent Samples t-Test data. As can be seen in Table 4.9, the mean scores of the follow-up tests of the experimental group $(\mathrm{M}=65.36, \mathrm{SD}=335)$ is higher of the control group $(\mathrm{M}=59.12, \mathrm{SD}=335)$. This mean difference $(\mathrm{MD}=6.24)$ was significantly different $(t=3.22$, sig. $=.01<0.05)$. Based on this, it can be said that what the students in the experimental group in which the English vocabulary teaching was performed with educational computer games had learned was more permanent than what the students in the control group in which the teaching was performed without with educational computer games

The effect size value of the result obtained as a result of the Independent Samples $\mathrm{t}$-Test is $\mathrm{d}=.35$. This value indicates that the size of the difference between the means of the scores obtained by the groups is little.

\subsubsection{Is there a significant difference between the academic achievement post-test scores and the follow-up test scores of the students included in the experimental and the control groups?}

To test this sub-research question was used the Dependent Samples t-Tests. The data relating to these tests is Table 4.11 and 4.12 below. The normality test results of the followup test and post-test scores of the experimental and control groups were given in Table 4.10 below. In the normality tests of the groups, the Kolmogorov-Smirnov p-value of the experimental group is to be $p=.003$ and the control group as $p=.053$. Since the obtained $p$ value is higher than $p=.05$, the data obtained from the groups show normal distribution in the control group. However, since the p-value obtained in the experimental group was lower than $\mathrm{p}=.05$, the skewness and the Kurtosis coefficient values, other ways of examining the normal distribution of data, were looked into. The coefficient of the skewness was found to be 0,154 and the Kurtosis coefficient was determined as .306. These values varied between -1 and +1 . Hence, according to the obtained values, the data showed normal distribution. Moreover, the skewness value was .154, and the skewness std. error value was .188 and when the skewness value was divided by the skewness std. error value (.154/.188), the value of .819 was reached. The Kurtosis coefficient was .306 and the Kurtosis std. error value was .375 and when the Kurtosis value was divided by the Kurtosis std. error value (.306 / .375), the value of .816 was found. It was observed that these values varied between -1.96 and +1.96 . By looking at these values, too, it can be said that the data showed normal distribution. 
Table 4 Results of the normality test related to the difference between the post-test scores and the follow-up test scores of the experimental and the control groups

\begin{tabular}{|l|c|c|c|}
\hline Kolmogorov-Smirnov & Statistics & $\mathbf{N}$ & $\mathbf{p}$ \\
\hline Group & .088 & 166 & .003 \\
\hline Experimental group difference & .068 & 171 & .053 \\
\hline Control group difference & &
\end{tabular}

The results of Dependent Samples t-Test related to the difference between the academic achievement post-test scores and the follow-up test scores of the experimental group were given in Table 4.11 below. As seen in the table, the student's follow-up test mean scores $(M=65.36, S D=165)$ is lower than their academic post-test mean scores $(M=68.52$, $\mathrm{SD}=165)$. There was a decrease in students' follow-up test scores compared to the posttest scores. The mean difference $(\mathrm{MD}=3.12)$ was statistical different $(t=-2,548$, sig. $=.012<$ 0.05). Based on this, it can be said that there was a decrease in the achievement levels of the students in the experimental group after one month.

Table 4.11: Results of the Dependent Samples t-Test applied to the post-test and the follow-up test achievement scores of the experimental group

\begin{tabular}{|l|c|c|c|c|c|c|}
\hline Experimental group & $\mathbf{N}$ & Mean & SD & Mean Difference & $\mathbf{t}$ & $\mathbf{p}$ \\
\cline { 1 - 3 } Post-test & 166 & 68.52 & \multirow{2}{*}{165} & 3.12 & $-2,548$ & \multirow{2}{*}{$\mathbf{0 1 2}$} \\
\cline { 1 - 6 } Follow-up test & 166 & 65.36 & & &
\end{tabular}

The effect size value of the result obtained as a result of the Dependent Samples t-Test is $d=.20$. This value indicates that the size of the difference between the mean of the posttest scores and that of the follow-up test scores the students who were taught English vocabulary with educational computer games is little.

The results of Dependent Samples t-Test related to the difference between the academic achievement post-test scores and the follow-up test scores of the control group were given in Table 4.12 below. As seen in the table, the student's follow-up test mean scores $(M=64.15, S D=170)$ is lower than their academic post-test mean scores $(M=59.12$, $\mathrm{SD}=170)$. There was a decrease in students' follow-up test scores compared to the posttest scores. The mean difference $(\mathrm{MD}=5.03)$ was statistical different $(\mathrm{t}=-3.532$, sig. $=.001<$ 0.05). Based on this, it can be said that there was a decrease in the achievement levels of the students in the control group after one month.

Table 4.12: Results of the Dependent Samples t-test applied to the post-test and the follow-up test achievement scores of control group

\begin{tabular}{|l|c|c|c|c|c|c|}
\hline Control group & $\mathbf{N}$ & Mean & SD & Mean Difference & $\mathbf{t}$ & $\mathbf{P}$ \\
\hline Post-test & 171 & 64.15 & \multirow{2}{*}{170} & 5.03 & -3.532 & \multirow{2}{*}{.001} \\
\hline Follow-up-test & 171 & 59.12 & & & \\
\hline
\end{tabular}

The effect size value of the result obtained as a result of the Dependent Samples t-Test is $\mathrm{d}=.27$. This value indicates that the size of the difference between the mean of the post- 
test scores and that of the follow-up scores of the students who were taught English vocabulary according to the existing program is little.

When students' post-test scores were compared with the follow-up test scores applied one month later, it was seen that there was a decrease in the scores of the students in both groups. This decrease was higher in the control group. The difference between the post-test and the follow-up scores was significant in both groups. This difference in both groups was little in terms of effect size.

\section{Discussion}

In this study, the effect of educational computer games developed by the researcher in English vocabulary teaching on students' academic achievement levels and the retention of what is learned was examined.

\subsection{Learning Achievement}

There is a statistically significant difference between the pre-test and the post-test achievement scores of included students in both groups. It could be concluded that there was a significant improvement in students' academic achievement in both groups after the study. According to the post-test results for both groups, the academic achievement means of the students in the experimental group is higher than the achievement means of the students in the control group. According to the statistical result, there is a significant difference in favor of the experimental group. According to this, it can be stated that the English vocabulary teaching performed with educational computer games had a higher effect on the students' achievement levels. The difference is little in terms of the size effect. This result is consistent with the meta-analysis study made by Chiu, Kao, and Reynolds (2012). In this study, it was determined that the drill and praxis types of games produced a little effect. When the drill and praxis types of games are designed well, they contribute to learning (Yip \& Kwan, 2006). Moreover, in some of the recentlymade literature analyses, it was found that the digital games supported vocabulary learning (Hung et al., 2018; Zou \& Xie, 2019). Similarly, some previous studies made with elementary school students indicated that DGVL promoted effective vocabulary teaching and learning (Aghlara \& Tamjid, 2011; Alsharafat, Alrashdan, \& Younes, 2017; Ashraf, Motlagh, \& Salami, 2014; Ceylaner \& Yanpar Yelken, 2017; Ebrahimzadeh, 2017; Jensen, 2017; Kocaman \& Kızılkaya Cumaoğlu, 2014; Letchumanan, Tan, Paramasivam, Sabariah, \& Muthusamy, 2015; Liu \& Chu, 2010; Yildırım, 2012; Hong et al., 2016). In the study carried out by Hung et al. (2015) with elementary school (6th grade) students, DGVL was found to affect the students with low success levels.

\subsection{Vocabulary Retention}

When post-test results are compared with follow-up test results one month later, it was observed that there was a decrease in the achievement scores of the students included in 
both the group. The difference between the post-test and the follow-up scores was significant in both groups. This difference in both groups was little in terms of effect size. According to the follow-up test results for both groups, the average score of students who learned words with educational computer games was higher than that of the other group. This difference is statistically significant. This difference was low in terms of effect size. Accordingly, it can be concluded that learning English vocabulary with educational computer games is more effective in providing retention. This result is similar to the findings of Donmuş (2012) and Yip and Kwan (2006). Yip and Kwan (2006) indicated that the students could retain the English vocabulary learned with games for a longer duration. Yip and Kwan (2006) also used drill and praxis game types as in present study. Young and Wang (2014) and Huang and Huang (2015) and the meta-analysis study of Zhang (2018) indicated that educational computer games did not affect long-term vocabulary retention. Young and Wang (2014) found in the vocabulary retention test applied one week after the implementation that the students in the control group using the drill and praxis method showed better performance than the students in the experimental group doing game-based exercise. However, the students in the experimental group focused more on speaking instead of memorizing the words during the game. Huang and Huang (2015) developed a handheld sensor-based vocabulary game based on the scaffolding strategy. The results indicated that all the students of different achievement levels in the experimental group had no better retention rate than the students in the control group. But the game they developed did not offer the students the chance for drill-and-practice. The researchers stated that this is why the game could not help students retain the vocabulary they learned in their long-term memory. Chang et al. (2016) also suggested, based on the findings of their studies, that when students are to take the chance to practice and practice, they can store knowledge in their long-term memories. These studies emphasize the importance of attention and drill in the long-term retention of learned vocabulary. Previous studies investigating the effect of spaced repetition at different ages in second language classes have revealed that this type of repetition affects retention (Varela, 2020). In our study, students played the educational games with one-week intervals by repeating them every week. These repetitions of the students may have affected the retention of what they learned.

\section{Conclusion}

According to the results, it can be suggested that the developed educational computer games are effective in achieving both better vocabulary learning and retention. According to this, these games can be used in the teaching of the vocabulary in the "My Town" unit in the existing secondary school 1st grade English Subject Teaching Program. In this way, we can support teachers by increasing their options for using games in their classrooms in teaching English vocabulary. Previous studies investigating the effect of spaced repetition at different ages in second language classes have revealed that this type of repetition affects retention (Varela, 2020). In this study, too, the students played the 
educational computer games with one-week repetition intervals during the experiment. Therefore, it can be suggested to teachers who are considering using the educational computer games developed in the present study, to plan their lessons by taking this result into account. Tsai, Cheng, Yeh, and Lin (2017) proved in their study examining the effect of digital games on language learning that a long experimental duration was needed to increase the effectiveness of students' learnings (Tsai, Cheng, Yeh, \& Lin, 2017). In this study, the students playing the developed games used six-lesson hours during four weeks. Therefore, new research can be conducted with a longer duration of the experiment.

\section{Conflict of Interest Statement}

The authors declare no conflicts of interests for this study.

\section{About the Authors}

Nuray Yilmaz works as an associate professor at the Department of Computer Education and Instructional Technology of the Faculty of Education at Bursa Uludag University. She has completed her undergraduate degree at the Department of Educational Curriculums and Instruction of the Faculty of Educational Sciences in Ankara University. Her degree of M.A. and $\mathrm{PhD}$ is in Educational Technology. Instructional design, instruction of information technologies, and technology integration are the subjects which she studies on.

Mahmut Zengin completed his master's degree at Bursa Uludag University, Institute of Educational Sciences.

\section{References}

Acquah EO, Katz HT, 2020. Digital Game-Based L2 learning Outcomes for Primary through High-School Students: A Systematic Literature Review, Computers \& Education 143: 103667. doi: 10.1016/j.compedu.2019.103667

Aghlara L, Tamjid NH, 2011. The Effect of Digital Games on Iranian Children's Vocabulary Retention in Foreign Language Acquisition, Procedia - Social and Behavioral Sciences 29: 552-560. doi: 10.1016/j.sbspro.2011.11.275

Aktaş T, 2005. Yabancı Dil Öğretiminde İletişimsel Yeti, Dil ve Dilbilimi Çalışmaları Dergisi, 89-100.

Alsharafat W, Alrashdan WK, Younes MB, 2017. The Effect of Using an Electronic Instructional Game in Improving English Language Vocabulary for Third Graders in Irbid City, International Journal of Interactive Mobile Technologies (IJIM), 11(6): 123-135. doi: 10.3991/ijim.v11i6.7417

Anşin S, 2006. Çocuklarda Yabancı Dil Öğretimi, D.Ü. Ziya Gökalp Eğitim Fakültesi, 920. 
Ashraf H, Motlagh FG, Salami M, 2014. The Impact of Online Games on Learning English Vocabulary by Iranian (Low-Intermediate) EFL Learners, Procedia-Social and Behavioral Sciences 98: 286-291. doi:10.1016/j.sbspro.2014.03.418

Büyüköztürk Ş, Çakmak EK, Akgün, ÖE, Karadeniz Ş, Demirel F, 2016. Bilimsel araştırma yöntemleri, Ankara, Pegem Akademi, Türkiye

Büyüköztürk Ş, Çokluk Ö, Köklü N, 2016. Sosyal bilimler için istatistik, Ankara, Pegem Akademi, Türkiye

Can A, 2018. Spss ile bilimsel araştırma sürecinde nicel veri analizi. Ankara, Pegem Akademi, Türkiye

Ceylaner S, Yanpar Yelken T, 2017. Ortaöğretim Öğrencilerinin Dijital Oyunların İngilizce Kelime Öğrenimine Katkısına Yönelik Görüşleri, Bartın Üniversitesi Eğitim Fakültesi Dergisi 6(1): 346-364.

Chang, RC, Chung LY, Huang, YM, 2016. Developing an interactive augmented reality system as a complement to plant education and comparing its effectiveness with video learning. Interactive Learning Environments, 24(6): 1245-1264. doi:10.1080/10494820.2014.982131.

Cheng J, Matthews J, 2018. The Relationship between Three Measures of L2 Vocabulary Knowledge and L2 Listening and Reading, Language Testing 35(1): 3-25. doi:10.1177/ 0265532216676851

Chiu YH, Kao CW, Reynolds, BL, 2012. The Relative Effectiveness of Digital Game-Based Learning Types in English as a Foreign Language Setting: A Meta-Analysis, British Journal of Educational Technology 43(4): E104-E107. doi:10.1111/j.14678535.2012.01295.x

Cornillie F, Clarebout G, Desmet P, 2012. Between Learning and Playing? Exploring Learners' Perceptions of Corrective Feedback in an Immersive Game for English Pragmatics, ReCALL, 24(3): 257-278. doi:10.1017/S0958344012000146

Donmuş V, 2012. İngilizce öğrenmede eğitsel bilgisayar oyunu kullanmanın erişiye, kalıcılığa ve motivasyona etkisi. Yüksek Lisans Tezi, Fırat Üniversitesi.

Ebrahimzadeh M, 2017. Readers, Players, and Watchers: EFL Students' Vocabulary Acquisition through Digital Video Games, English Language Teaching 10 (2): 1-18. doi:10.5539/elt. v10n2p1

Godwin-Jones R, 2014. Games in Language Learning: Opportunities and Challenges. Language, Learning and Technology 18(2): 9-19.

Gömleksiz MN, Aslan S, 2017. Ortaokul Öğrencilerinin İngilizce Öğgreniminde Karşılaştıkları Sorunlara İlişkin Görüşleri: Nitel Bir Çalışma, The Journal of Academic Social Science Studies 64: 1-13.

Hong JS, Han DH, Kim YI, Su JB, Sun MK, Renshaw P, 2016. English Language Education On-Line Game and Brain Connectivity, ReCALL 29(1): 3-21. doi:10.1017/S0958344016000173

Huang YM, Huang YM, 2015. A Scaffolding Strategy to Develop Handheld Sensor-Based Vocabulary Games for Improving Students' Learning Motivation and 
Performance, Educational Technology Research and Development 63(5); 691-708. doi:10.1007/s11423-015-9382-9.

Hung HC, Young SS, Lin CP, 2015. No Student Left Behind: A Collaborative and Competitive Game-Based Learning Environment to Reduce the Achievement Gap of EFL Students in Taiwan, Technology, Pedagogy and Education 24(1): 35-49. doi: 10.1080/1475939X.2013.822412

Hung H, Yang JC, Hwang G, Chu H, Wang C, 2018. A Scoping Review of Research on Digital Game-Based Language Learning, Computers \& Education 126: 89-104. doi:10.1016/j. Compedu.2018.07.001.

Hwang GJ, Wu PH, 2012. Advancements and Trends in Digital Game-Based Learning Research: A Review of Publications in Selected Journals from 2001 to 2010, British Journal of Educational Technology 43(1): E6-E10. doi:10.1111/j.14678535.2011.01242.x

Jensen, SH, 2017. Gaming as an English Language Learning Resource among Young Children in Denmark, Calico Journal 34(1): 1-19. doi:10.1558/cj.29519

Kocaman O, Kızılkaya Cumaoğlu G, 2014. Eğitsel Yazılım (DENIS) ve Oyunlarla İngilizce Kelime Öğretiminin Kelime Öğrenme Stratejilerine ve Başarıya Etkisi, Eğitim ve Bilim 39 (176): 305-316. doi: 10.15390/EB.2014.3704

Lervåg A, Aukrust, VG, 2010. Vocabulary Knowledge is a Critical Determinant of the Difference in Reading Comprehension Growth between First and Second Language Learners, Journal of Child Psychology and Psychiatry 51(5): 612-620. doi: 10.1111/j.1469-7610. 2009.02185.x

Letchumanan K, Tan BH, Paramasivam S, Sabariah MR, Muthusamy P, 2015. Incidental Learning of Vocabulary through Computer-Based and Paper-Based Games by Secondary School ESL Learners, Pertanika Journal of Social Sciences \& Humanities 23(3): 725-740.

Li M, Kirby JR, 2015. The Effect of Vocabulary Breadth and Depth on English Reading, Applied Linguistics 36 (5): 611-634. doi:10.1093/applin/amu007

Liu TY, Chu YL, 2010. Using Ubiquitous Games in an English Listening and Speaking Course: Impact on Learning Outcomes and Motivation, Computers \& Education 55(2): 630-643. doi: 10.1016/j.compedu.2010.02.023

Masrai A, 2019. Vocabulary and Reading Comprehension Revisited: Evidence for HighMid-, and Low-Frequency Vocabulary Knowledge, Sage Open 9(2): 1-13. doi: $10.1177 / 2158244019845182$

Matthews J, 2018. Vocabulary for Listening: Emerging Evidence for High and MidFrequency Vocabulary Knowledge, System, 72 23-36. doi:10.1016/j. system.2017.10.005

Matthews J, Cheng J, 2015. Recognition of High Frequency Words from Speech as a Predictor of L2 Listening Comprehension. System, 52, 1-13. doi: 10.1016/j.system.2015. 04.015

Oflaz A, 2017. Duygusal Uyartı Kullanımının Öğrencilerin Kelime Hazinesi Geliştirme Sürecine ve Kelime Kalıcılık Düzeyine Etkileri. Turkish Studies International 
Periodical for the Languages, Literature and History of Turkish or Turkic 12/17: 246-274. doi: 10.7827/TurkishStudies.11891

Poole FJ, Clarke-Midura J, 2020. A Systematic Review of Digital Games in Second Language Learning Studies. International Journal of Game-Based Learning (IJGBL) 10 (3):1-15. doi: 10.4018/IJGBL.2020070101

Prensky M, 2001. Digital game based learning. New York, London, McGraw-Hill.

Qian DD, 2002. Investigating the Relationship between Vocabulary Knowledge and Academic Reading Performance: An Assessment Perspective, Language Learning 52(3): 513-536. doi: 10.1111/1467-9922.00193

Schmitt N, 2008. Instructed Second Language Vocabulary Learning, Language Teaching Research 12(3): 329-363. doi:10.1177/1362168808089921

Sezgin S, Binark M, Yalçın H, Bayraktutan, G. (2018). Türkiye'de Dijital Oyun Çalışmalarının 10 Yılı: Bir Tubitak-Sobag Araştırmasının Boylamsal Etki Değerlendirmesi, Kültür ve İletişim 21 (42): 170-194.

Sönmez TM, Artut DP, 2012. Web üzerinden sunulan eğitsel matematik oyunlarının kesirler ve ondalık sayılara ilişkin öğrenci başarısına etkisi. http://91.239.204.115/handle/11547/715. Accessed 25 April 2018

Stæhr L, 2008. Vocabulary Size and the Skills of Listening, Reading and Writing, Language Learning Journal, 36 (2), 139-152. doi: 10.1080/09571730802389975

$\mathrm{Su}$ YC, 2008. Effects of computer game-based instruction on programming achievement of adult students in Taiwan. PhD Thesis, University of La Sierra. https://www.proquest.com/docview/304813342. Accessed 05 February 2019

Sundqvist P, Wikström P, 2015. Out-Of-School Digital Gameplay and In-School L2 English Vocabulary Outcomes, System 51: 65-76. doi: 10.1016/j.system.2015.04.001

Tsai CH, Cheng CH, Yeh DY, Lin SY, 2017. Can Learning Motivation Predict Learning Achievement? A Case Study of a Mobile Game-Based English Learning Approach, Education and Information Technologies 22(5): 2159-2173. doi: 10.1007/s10639016-9542-5

Tsai YL, Tsai CC, 2018. Digital Game-Based Second-Language Vocabulary Learning and Conditions of Research Designs: A Meta-Analysis Study, Computers \& Education 125, 345-357. doi: 10.1016/j.compedu.2018.06.020

Varela MA, 2020. Vocabulary retention in a spaced repetition longitudinal field study with high-school language learners. PhD Thesis, University of Swansea. https://core.ac.uk/download/pdf/287586011.pdf. Accessed 05 February 2018

Yıldırım, N. (2012). Yabancı dil eğitiminde eğitsel oyunlar aracıllğı̆yla mobil öğrenme. Yüksek Lisans Tezi, Frrat Üniversitesi.

Yip F, Kwan A, 2006. Online Vocabulary Games as a Tool for Teaching and Learning English Vocabulary, Educational Media International 43(3): 233-249.doi: 10.1080/09523980600641445

Young MF, Slota S, Cutter AB, Jalette G, Mullin G, Lai B, Yukhymenko M, 2012. Our Princess is in Another Castle: A Review of Trends in Serious Gaming for Education, Review of Educational Research 82(1): 61-89. doi: 10.3102/0034654312436980 
Young SS, Wang Y, 2014. The Game Embedded CALL System to Facilitate English Vocabulary Acquisition and Pronunciation, Journal of Educational Technology \& Society 17(3): 239-251.

Zhang H, 2018. A literature review and meta-analysis of digital games and second language learning. Master Thesis, University of Windsor.

Zou DH, Huang Y, Xie, H. (2021). Digital Game-Based Vocabulary Learning: Where are We and Where are We Going?, Computer Assisted Language Learning 34(5-6): 751-777, doi: 10.1080/09588221.2019.1640745 
Creative Commons licensing terms

Authors will retain the copyright of their published articles agreeing that a Creative Commons Attribution 4.0 International License (CC BY 4.0) terms will be applied to their work. Under the terms of this license, no permission is required from the author(s) or publisher for members of the community to copy, distribute, transmit or adapt the article content, providing a proper, prominent and unambiguous attribution to the authors in a manner that makes clear that the materials are being reused under permission of a Creative Commons License. Views, opinions, and conclusions expressed in this research article are views, opinions and conclusions of the author(s). Open Access Publishing Group and European Journal of English Language Teaching shall not be responsible or answerable for any loss, damage or liability caused in relation to/arising out of conflict of interests, copyright violations and inappropriate or inaccurate use of any kind content related or integrated on the research work. All the published works are meeting the Open Access Publishing requirements and can be freely accessed, shared, modified, distributed and used in educational, commercial and non-commercial purposes under a Creative Commons Attribution 4.0 International License (CC BY 4.0). 